\section{PEMBERLAKUAN SANKSI HUKUM TERHADAP PELAKU USAHA PANGAN AKIBAT MELAKUKAN PELANGGARAN TERHADAP UNDANG-UNDANG NOMOR 18 TAHUN 2012 TENTANG PANGAN ${ }^{1}$ \\ Oleh : Praishilia Adolong ${ }^{2}$}

\begin{abstract}
ABSTRAK
Tujuan dilakukannya penelitian ini adalah untuk mengetahui bagaimana bentuk-bentuk perbuatan pelaku usaha pangan yang dapat dikenakan sanksi hukum berdasarkan UndangUndang Nomor Nomor 18 Tahun 2012 tentang Pangan dan bagaimana pemberlakuan sanksi hukum terhadap pelaku usaha pangan akibat melakukan pelanggaran terhadap UndangUndang Nomor Nomor 18 Tahun 2012 tentang Pangan. Dengan menggunakan metode penelitian yuridis normatif, disimpulkan: 1 . Bentuk-bentuk perbuatan pelaku usaha pangan yang dapat dikenakan sanksi hukum seperti menimbun atau menyimpan pangan pokok melebihi jumlah maksimal. Menimbun adalah menyimpan melebihi batas yang diperbolehkan dengan maksud untuk memperoleh keuntungan yang mengakibatkan harga pangan pokok menjadi mahal dan/atau melambung tinggi dan pelaku usaha pangan yang dengan sengaja tidak memiliki izin edar terhadap setiap pangan olahan yang dibuat di dalam negeri atau yang diimpor untuk diperdagangkan dalam kemasan eceran. 2. Pemberlakuan sanksi hukum terhadap pelaku usaha pangan akibat melakukan pelanggaran seperti menimbun atau menyimpan pangan pokok melebihi jumlah maksimal, maka pelaku usaha pangan dikenai sanksi administratif, berupa: denda; penghentian sementara dari kegiatan, produksi, dan/atau peredaran; dan/atau pencabutan izin. Apabila pelaku usaha pangan terbukti melakukan perbuatan dengan unsur kesengajaan maka dapat dikenakan pidana penjara paling lama 7 (tujuh) tahun atau denda paling banyak Rp100.000.000.000,00 (seratus miliar rupiah). Pelaku Usaha Pangan yang dengan sengaja tidak memiliki izin edar terhadap setiap pangan olahan yang dibuat di dalam negeri atau yang diimpor untuk diperdagangkan dalam kemasan eceran
\end{abstract}

\footnotetext{
${ }^{1}$ Artikel Skripsi. Dosen Pembimbing: Nontje Rimbing, SH, MH; Fernando J. M. M. Karisoh, SH, MH

2 Mahasiswa pada Fakultas Hukum Unsrat, NIM.13071101157
}

dipidana dengan pidana penjara paling lama 2 (dua) tahun atau denda paling banyak Rp4.000.000.000,00 (empat miliar rupiah).

Kata kunci: Pemberlakuan Sanksi Hukum, Pelaku Usaha, Pangan, Pelanggaran.

\section{PENDAHULUAN}

\section{A. Latar Belakang}

Perwujudan ketersediaan pangan yang berbasis pada pemanfaatan sumber daya lokal secara optimal dilakukan dengan penganekaragaman pangan dan pengutamaan produksi pangan dalam negeri. Pewujudan keterjangkauan pangan dari aspek fisik dan ekonomi dilakukan melalui pengelolaan stabilisasi pasokan dan harga pangan pokok, pengelolaan cadangan pangan pokok, dan pendistribusian pangan pokok. Pemanfaatan pangan atau konsumsi pangan dan gizi akan menghasilkan sumber daya manusia yang berkualitas sebagai salah satu faktor penentu keberhasilan pembangunan. Hal itu dilakukan melalui pemenuhan asupan pangan yang beragam, bergizi seimbang, serta pemenuhan persyaratan keamanan pangan, mutu pangan, dan gizi pangan. ${ }^{3}$

Penyelenggaraan keamanan pangan untuk kegiatan atau proses produksi pangan untuk dikonsumsi harus dilakukan melalui sanitasi pangan, pengaturan terhadap bahan tambahan pangan, pengaturan terhadap pangan produk rekayasa genetik dan Iradiasi Pangan, penetapan standar kemasan pangan, pemberian jaminan keamanan pangan dan mutu pangan, serta jaminan produk halal bagi yang dipersyaratkan. Pelaku usaha pangan dalam melakukan produksi pangan harus memenuhi berbagai ketentuan mengenai kegiatan atau proses produksi pangan sehingga tidak berisiko merugikan atau membahayakan kesehatan manusia. Pelaku usaha pangan bertanggung jawab terhadap pangan yang diedarkan, terutama apabila pangan yang diproduksi menyebabkan kerugian, baik terhadap gangguan kesehatan maupun kematian orang yang mengonsumsi pangan tersebut.

Masyarakat juga perlu mendapatkan informasi yang jelas mengenai setiap produk pangan yang dikemas sebelum membeli dan

\footnotetext{
${ }^{3}$ Penjelasan Atas Undang-Undang Nomor 18 Tahun 2012 tentang Pangan.
} 
mengonsumsi Pangan. Informasi tersebut terkait dengan asal, keamanan, mutu, kandungan gizi, dan keterangan lain yang diperlukan. Sehubungan dengan hal tersebut, perlu ditetapkan ketentuan mengenai label dan iklan pangan sehingga masyarakat dapat mengambil keputusan berdasarkan informasi yang akurat. Keberlanjutan dalam pewujudan kedaulatan pangan, kemandirian pangan, dan ketahanan pangan bergantung kepada kemampuan bangsa dan negara dalam menciptakan inovasi teknologi di bidang pangan serta mendiseminasikannya kepada pelaku usaha pangan. Oleh karena itu, pemerintah wajib melakukan penelitian dan pengembangan Pangan secara terus-menerus, dan mendorong serta menyinergikan kegiatan penelitian dan pengembangan pangan yang dilakukan oleh pemerintah daerah, lembaga pendidikan, lembaga penelitian, pelaku usaha pangan, dan masyarakat. ${ }^{4}$

Negara berkewajiban untuk menjamin ketersediaan pangan dalam jumlah yang cukup (selain terjamin mutunya) bagi setiap warga negara, karena pada dasarnya setiap warga negara berhak atas pangan bagi keberlangsungan hidupnya. Penyediaan pangan oleh negara harus diupayakan melalui produksi pangan dalam negeri, di mana produksi ini harus senantiasa meningkat dari tahun ke tahun seiring dengan pertambahan penduduk. ${ }^{5}$

Permasalahan secara umum mengenai ketahanan pangan adalah jumlah penduduk yang besar dengan pertumbuhan penduduk yang positif. Dengan demikian permintaan pangan masih akan meningkat. Peningkatan permintaan pangan juga didorong oleh peningkatan pendapatan, kesadaran akan kesehatan dan pergeseran pola makan karena pengaruh globalisasi, serta ragam aktivitas masyarakat. Di sisi lain, ketersediaan sumber daya lahan semakin berkurang, karena tekanan penduduk serta persaingan pemanfaatan lahan antara sektor pangan dengan sektor non pangan. Secara spesifik, permasalahan sehubungan dengan ketahanan pangan adalah penyediaan, distribusi, dan konsumsi pangan. ${ }^{6}$

\footnotetext{
${ }^{4}$ Undang-Undang Nomor 18 Tahun 2012 tentang Pangan.

${ }^{5}$ Yunastiti Purwaningsih Ketahanan Pangan: Situasi, Permasalahan, Kebijakan, Dan Pemberdayaan Masyarakat. Jurnal Ekonomi Pembangunan.Vol. 9, No. 1, Juni 2008, hlm. 3.

${ }^{6}$ Ibid. hlm. 15.
}

Apabila terjadi pelanggaran hukum di bidang pangan yang telah terbukti secara sah dilakukan oleh pelaku usaha pangan, maka akibat perbuatan tersebut pelaku usaha pangan dapat dikenakan sanksi hukum berupa sanksi adminsitratif dan sanksi pidana. pemberlakuan sanksi hukum terhadap pelaku usaha pangan merupakan bagian dari upaya penegakan hukum untuk mencegah terjadinya perbuatan pelanggaran hukum di bidang pangan yang dapat menimbulkan kerugian bagi masyarakat.

\section{B. Rumusan Masalah}

1. Bagaimanakah bentuk-bentuk perbuatan pelaku usaha pangan yang dapat dikenakan sanksi hukum berdasarkan Undang-Undang Nomor Nomor 18 Tahun 2012 tentang Pangan?

2. Bagaimanakah pemberlakuan sanksi hukum terhadap pelaku usaha pangan akibat melakukan pelanggaran terhadap UndangUndang Nomor Nomor 18 Tahun 2012 tentang Pangan?

\section{Metode Penelitian}

Penulisan ini disusun menggunakan metode penelitian hukum normatif. Bahan-bahan hukum yang diperlukan diperoleh dari hasil studi kepustakaan, seperti peraturan perundang-undangan sebagai bahan hukum primer. Literatur-literatur dan karya-karya ilmiah hukum sebagai hukum sekunder dan bahan-bahan hukum tersier dan juga seperti kamus-kamus hukum.

Penelitian hukum yang dilakukan dengan cara meneliti bahan pustaka atau data sekunder belaka, dapat dinamakan penelitian hukum normatif atau penelitian hukum kepustakaan (di samping adanya penelitian hukum sosiologis atau empiris yang terutama meneliti data primer). ${ }^{7}$ Penelitian hukum normatif, data sekunder sebagai sumber/bahan informasi dapat merupakan bahan hukum primer, bahan hukum sekunder. ${ }^{8}$

\section{PEMBAHASAN}

\footnotetext{
${ }^{7}$ Soerjono Soekanto dan Sri Mamudji, Penelitian Hukum Normatif Suatu Tinjauan Singkat, PT Raja Grafindo Persada, Jakarta. 1995, hlm. 13-14.

${ }^{8}$ Suratman, dan H. Philips Dillah, Metode Penelitian Hukum. Alfabetah, Bandung. 2015.hlm. 107.
} 


\section{A. Bentuk-Bentuk Perbuatan Pelaku Usaha Pangan Yang Dapat Dikenakan Sanksi Hukum}

Pembangunan nasional merupakan pencerminan kehendak seluruh rakyat untuk terus-menerus meningkatkan kemakmuran dan kesejahteraannya secara adil dan merata dalam segala aspek kehidupan yang dilakukan secara terpadu, terarah, dan berkelanjutan dalam rangka mewujudkan suatu masyarakat yang adil dan makmur, baik material maupun spiritual berdasarkan Pancasila dan UndangUndang Dasar Negara Republik Indonesia Tahun 1945. ${ }^{9}$

Pangan merupakan kebutuhan dasar manusia yang paling utama dan pemenuhannya merupakan bagian dari hak asasi setiap rakyat Indonesia. Pangan harus senantiasa tersedia secara cukup, aman, bermutu, bergizi, dan beragam dengan harga yang terjangkau oleh daya beli masyarakat, serta tidak bertentangan dengan agama, keyakinan, dan budaya masyarakat. Untuk mencapai semua itu, perlu diselenggarakan suatu sistem Pangan yang memberikan pelindungan, baik bagi pihak yang memproduksi maupun yang mengonsumsi pangan. ${ }^{10}$

Bentuk-bentuk perbuatan pelaku usaha pangan yang dapat dikenakan sanksi hukum, sebagaimana diatu dalam Undang-Undang Nomor 18 Tahun 2012 tentang Pangan, diatur dalam Pasal 53. Pelaku Usaha Pangan dilarang menimbun atau menyimpan Pangan Pokok melebihi jumlah maksimal sebagaimana dimaksud dalam Pasal 52.

Pasal 52 ayat:

(1) Dalam hal Perdagangan Pangan, Pemerintah menetapkan mekanisme, tata cara, dan jumlah maksimal penyimpanan Pangan Pokok oleh Pelaku Usaha Pangan.

(2) Ketentuan mengenai mekanisme, tata cara, dan jumlah maksimal sebagaimana dimaksud pada ayat (1) diatur dengan atau berdasarkan pada Peraturan Pemerintah.

Penjelasan Pasal 53. Yang dimaksud dengan "menimbun" adalah menyimpan melebihi batas yang diperbolehkan dengan maksud untuk memperoleh keuntungan yang mengakibatkan

\footnotetext{
${ }^{9}$ Penjelasan Atas Undang-Undang Nomor 18 Tahun 2012 tentang Pangan.

${ }^{10}$ Undang-Undang Nomor 18 Tahun 2012 tentang Pangan.
}

harga Pangan Pokok menjadi mahal dan/atau melambung tinggi.

Larang; melarang; memerintahkan supaya tidak melakukan sesuatu; tidak memperbolehkan berbuat sesuatu. ${ }^{11}$

Undang-Undang Nomor 18 Tahun 2012 tentang Pangan. Pasal 142. Pelaku Usaha Pangan yang dengan sengaja tidak memiliki izin edar terhadap setiap Pangan Olahan yang dibuat di dalam negeri atau yang diimpor untuk diperdagangkan dalam kemasan eceran sebagaimana dimaksud dalam Pasal 91 ayat (1) dipidana dengan pidana penjara paling lama 2 (dua) tahun atau denda paling banyak Rp4.000.000.000,00 (empat miliar rupiah).

Pasal 91 ayat:

(1) Dalam hal pengawasan keamanan, mutu, dan Gizi, setiap Pangan Olahan yang dibuat di dalam negeri atau yang diimpor untuk diperdagangkan dalam kemasan eceran, Pelaku Usaha Pangan wajib memiliki izin edar.

(2) Kewajiban memiliki izin edar sebagaimana dimaksud pada ayat (1) dikecualikan terhadap Pangan Olahan tertentu yang diproduksi oleh industri rumah tangga.

(3) Ketentuan mengenai kewajiban memiliki izin edar sebagaimana dimaksud pada ayat (1) dan ayat (2) dilaksanakan sesuai dengan ketentuan peraturan perundang-undangan.

Penjelasan Pasal 91 ayat (2) Yang dimaksud dengan "Pangan Olahan tertentu" adalah pangan olahan yang dibuat oleh industri rumah tangga Pangan, yaitu industri Pangan yang memiliki tempat usaha di tempat tinggal dengan peralatan pengolahan manual hingga semi otomatis.

Korporasi sebagai subjek hukum tidak hanya menjalankan kegiatannya sesuai dengan prinsip ekonomi (mencari keuntungan yang sebesarbesarnya), tetapi juga mempunyai kewajiban untuk mematuhi peraturan hukum di bidang ekonomi yang digunakan pemerintah guna mewujudkan kesejahteraan masyarakat dan keadilan sosial. ${ }^{12}$

\section{B. PEMBERLAKUAN SANKSI HUKUM TERHADAP PELAKU USAHA PANGAN}

\footnotetext{
${ }^{11}$ Sudarsono, Op.Cit. hlm. 242.

${ }^{12}$ Alvi Syahrin, Beberapa Isu Hukum Lingkungan Kepidananaan, Cetakan Revisi, PT. Sofmedia, Jakarta, Mei 2009, hlm. 59.
} 


\section{AKIBAT MELAKUKAN PELANGGARAN TERHADAP UNDANG-UNDANG NOMOR NOMOR 18 TAHUN 2012 TENTANG PANGAN}

Pemberlakuan sanksi hukum terhadap pelaku usaha pangan akibat melakukan pelanggaran terhadap Undang-Undang Nomor Nomor 18 Tahun 2012 Tentang Pangan, dapat dikenakan sanksi administratif dan sanksi pidana, sebagaimana dinyatakan pada Pasal 53. Pelaku Usaha Pangan dilarang menimbun atau menyimpan Pangan Pokok melebihi jumlah maksimal sebagaimana dimaksud dalam Pasal 52. Pasal 52 ayat:

(1) Dalam hal Perdagangan Pangan, Pemerintah menetapkan mekanisme, tata cara, dan jumlah maksimal penyimpanan Pangan Pokok oleh Pelaku Usaha Pangan.

(2) Ketentuan mengenai mekanisme, tata cara, dan jumlah maksimal sebagaimana dimaksud pada ayat (1) diatur dengan atau berdasarkan pada Peraturan Pemerintah.

Penjelasan Pasal 53. Yang dimaksud dengan "menimbun" adalah menyimpan melebihi batas yang diperbolehkan dengan maksud untuk memperoleh keuntungan yang mengakibatkan harga Pangan Pokok menjadi mahal dan/atau melambung tinggi.

Pasal 54 ayat:

(1) Pelaku Usaha Pangan yang melanggar ketentuan sebagaimana dimaksud dalam Pasal 53 dikenai sanksi administratif.

(2) Sanksi administratif sebagaimana dimaksud pada ayat (1) berupa:

a. denda;

b. penghentian sementara dari kegiatan, produksi, dan/atau peredaran; dan/atau

c. pencabutan izin.

(3) Ketentuan lebih lanjut mengenai jenis, besaran denda, tata cara, dan mekanisme pengenaan sanksi administratif sebagaimana dimaksud pada ayat (1) dan ayat (2) diatur dalam Peraturan Pemerintah.

Pasal 133. Pelaku Usaha Pangan yang dengan sengaja menimbun atau menyimpan melebihi jumlah maksimal sebagaimana dimaksud dalam Pasal 53 dengan maksud untuk memperoleh keuntungan yang mengakibatkan harga Pangan Pokok menjadi mahal atau melambung tinggi dipidana dengan pidana penjara paling lama 7 (tujuh) tahun atau denda paling banyak Rp100.000.000.000,00 (seratus miliar rupiah).

Pasal 142. Pelaku Usaha Pangan yang dengan sengaja tidak memiliki izin edar terhadap setiap Pangan Olahan yang dibuat di dalam negeri atau yang diimpor untuk diperdagangkan dalam kemasan eceran sebagaimana dimaksud dalam Pasal 91 ayat (1) dipidana dengan pidana penjara paling lama 2 (dua) tahun atau denda paling banyak Rp4.000.000.000,00 (empat miliar rupiah).

Pidana denda merupakan bentuk pidana tertua. Pidana ini terdapat pada setiap masyarakat termasuk pada masyarakat adat. Dalam masyarakat adat Bali terdapat denda yang dikenakan pada orang yang membuat kesalahan dan mengakibatkan tidak stabilnya keseimbangan masyarakat adat tersebut. Pada saat sekarang pidana denda dijatuhkan terhadap tidak pidana ringan berupa pelanggaran atau kejahatan ringan. Pidana denda merupakan pidana satu-satunya pidana yang dapat dipikul oleh orang lain selain terpidana. Walaupun denda dijatuhkan terhadap terpidana pribadi tidak ada larangan jika denda itu secara sukarela dibayar oleh orang lain atas nama terpidana. Hasil penagihan denda diperuntukkan bagi kas negara, walaupun peraturan pidana itu dibuat oleh pemerintah daerah begitu pula biaya untuk pidana kurungan pengganti di tanggung oleh negara walaupun peraturan pidana itu dibuat oleh pemerintah daerah pula. ${ }^{13}$

Denda; hukum yang berupa keharusan membayar dalam bentuk uang atau lainnya karena melanggar aturan, undang-undang atau aturan-aturan lain yang hidup di tengah-tengah masyarakat. $^{14}$

Beberapa sarjana hukum mengemukakan tentang tujuan hukum pidana, ialah:

a. Untuk menakut-nakuti orang jangan sampai melakukan kejahatan, baik dengan menakutnakuti orang banyak (generale preventie), maupun secara menakut-nakuti orang tertentu yang sudah menjalankan kejahatan, agar dikemudian hari tidak melakukan kejahatan lagi (special prventie);

b. Untuk mendidik atau memperbaiki orangorang yang suka melakukan kejahatan agar

\footnotetext{
${ }^{13}$ Evi Hartanti, Tindak Pidana Korupsi, Ed. 2. Cet. 1. Sinar Grafika, Jakarta, 2007, hlm. 58.

${ }^{14}$ Sudarsono, Kamus Hukum, Cet. 6. Rineka Cipta, Jakarta, 2009, hlm. 94.
} 
menjadi orang yang baik tabiatnya, sehingga bermanfaat bagi masyarakat;

c. Untuk mencegah dilakukannya tindak pidana demi pengayoman negara, masyarakat dan penduduk, yakni:

1) Untuk membimbing agar terpidana insaf dan menjadi anggota masyarakat yang berbudi baik dan berguna;

2) Untuk menghilangkan noda-noda yang diakibatkan oleh tindak pidana. ${ }^{15}$

Saat ini Indonesia sedang dilanda krisis perekonomian, yang ditandai dengan rendahnya nilai rupiah terhadap dollar, banyaknya investasi asing yang keluar dari wilayah NKRI, rendahnya produksi dari industri manufaktur, sampai dengan ancaman gelombang PHK. Selain itu, kondisi ini diperparah dengan naiknya harga-harga kebutuhan pangan akibat keterbatasan persediaannya. Terdapat beberapa faktor yang mempengaruhi keterbatasan ketersediaan pangan, diantaranya adalah gagal panen akibat kemarau yang berkepanjangan, mata rantai distribusi yang tidak efektif, sampai dengan adanya unsur kesengajaan berupa penimbunan pangan dari pihak-pihak tertentu dengan maksud untuk memperoleh keuntungan yang mengakibatkan harga pangan pokok menjadi mahal atau melambung tinggi. ${ }^{16}$

Terkait dengan kasus penimbunan pangan, baru-baru ini Badan Reserse Kriminal (Bareskrim) Mabes Polri bertindak cepat atas temuan dugaan penimbunan sapi yang dilakukan di dua peternakan sapi di daerah Tangerang, Banten yakni PT. Brahman Perkasa Sentosa (BPS) dan PT Tanjung Unggul Mandiri (TUM). Setelah melakukan pemeriksaan pada hari Rabu 12 Agustus 2015 malam, polisi segera memeriksa sejumlah pihak yang diduga turut terlibat dalam penimbunan sapi impor siap potong itu. Selain itu di perusahaan penggemukan (feedloter) yang lain, PT Widodo Makmur Perkasa di Cilengsi, Bogor, juga terindikasi melakukan hal yang sama. Hal ini menyebabkan harga normal sapi hidup perkilogram biasanya Rp.38.000,- sampai

\footnotetext{
${ }^{15}$ Siswantoro Sunarso, Hukum Pidana Lingkungan Hidup Dan Strategi Penyelesaian Sengketa, Cetakan Pertama, Rineka Cipta, Jakarta, 2005, hlm. 73.

${ }^{16}$ Zaqiu Rahman. Problematika Penegakan Hukum Terhadap Pelaku Tindak Pidana Penimbunan Pangan. RechtsVinding Online. Jurnal RechtsVinding. Media Pembinaan Hukum Nasional. hlm. 1.
}

dengan Rp.39.000,-, tetapi sejak Agustus 2015 perusahaan penggemukan sapi (feedloter) menaikan harganya hingga Rp.43.000,- per kg. Hal ini tentu saja menimbulkan kecurigaan, karena biasanya pascalebaran seharusnya harga daging sapi turun tetapi kali ini justru semakin tinggi (http://www.rmol.co/). ${ }^{17}$

Pengusutan kasus tersebut berawal dari naiknya harga daging sapi beberapa waktu lalu, sehingga memicu para pedagang melakukan aksi mogok. Bareskrim menemukan bukti-bukti pelarangan pemotongan sapi dan dilakukan secara sengaja. Kesengajaan tersebut dilaksanakan secara terstruktur lewat cara mengeluarkan surat edaran pelarangan memotong sapi sehingga terciptakan kondisi kelangkaan daging sapi khususnya di wilayah Jakarta. Akibatnya, para pedagang daging tidak mendapat pasokan sehingga tak bisa berjualan. Dengan kata lain, upaya mengeluarkan edaran larangan pemotongan sapi, bisa dikategorikan sebagai salah satu upaya penimbunan pangan (http://www.rmol.co). ${ }^{18}$

Untuk merespon agar kasus-kasus tersebut tidak terulang, Kepala Kepolisian Republik Indonesia telah mengeluarkan Maklumat Nomor MAK/01/VIII/2015 tentang Larangan Melakukan Penimbunan atau Penyimpanan Pangan dan Barang Kebutuhan Pokok. Terdapat dua hal pokok yang dilarang dilakukan oleh para pedagang, yaitu pertama, pelaku usaha dilarang menimbun atau menyimpan melebihi jumlah maksimal yang diperbolehkan atau di luar batas kewajaran, dengan maksud untuk memperoleh keuntungan sehingga mengakibatkan bahan pokok menjadi mahal atau melambung tinggi; dan kedua, pelaku usaha juga dilarang menyimpan barang kebutuhan pokok atau barang penting dalam jumlah atau waktu tertentu pada saat kelangkaan barang, gejolak harga, atau hambatan lalu lintas perdagangan (http://www.cnnindonesia.com). ${ }^{19}$

Salah satu jenis pidana pokok yang diatur dalam Pasal 10 KUHP adalah pidana denda. KUHP itu sendiri, berdasarkan UU No. 1 Tahun 1946 j.o. UU No. 73 Tahun 1958 adalah berasal dari Wetboek van Strafrecht voor Nederlands Indie yang mulai berlaku di Indonesia pada

\footnotetext{
${ }^{17}$ Ibid. hlm. 1.

18 Ibid. hlm. 2.

${ }^{19}$ Ibid..
} 
tanggal 1 Januari 1918. ${ }^{20}$ Pidana denda: pembayaran sejumlah uang oleh terpidana berdasarkan putusan pengadilan. Pidana denda dapat digantikan dengan pidana kurungan jika denda tidak dibayarkan. ${ }^{21}$

Pidana "denda" adalah pidana pembebanan sejumlah uang terhadap dan harus dibayar oleh Korporasi yang terbukti secara sah dan meyakinkan bersalah melakukan tindak pidana berdasarkan putusan Pengadilan yang telah mempunyai kekuatan hukum tetap. ${ }^{22}$ Menurut Adriano:

1. Bahwa pidana denda tidak mungkin berdiri sendiri (mandiri) dalam pertanggungjawaban pidana korporasi, dan oleh karenanya diperlukan adanya pidana pengganti sebagai substitusi jika pidana denda tidak dilaksanakan.

2. Bahwa bentuk pidana yang paling sesuai dengan karakteristik Korporasi adalah pidana yang berkaitan dengan organisasi, status subyek hukum dan harta kekayaan. Pidana dari sisi organisasi antara lain pembekuan untuk jangka waktu tertentu hingga pembubaran Korporasi, sedangkan pidana dari sisi status subyek hukum adalah pencabutan status badan hukum, dan pidana dari sisi harta kekayaan adalah denda.

3. Dalam penerapan pidana denda terhadap Korporasi wajib disubstitusikan dengan pidana "pembekuan untuk jangka waktu tertentu"sebagai pidana pengganti. ${ }^{23}$

Pada jaman kerajaan Majapahit, sanksi pidana denda biasanya dikenakan pada kasuskasus penghinaan atau pencurian dan pembunuhan binatang piaraan yang menjadi kesenangan raja. Dalam menetapkan besar atau kecilnya denda tergantung pada besar atau kecilnya kesalahan yang diperbuat, yaitu dapat diperinci sebagai berikut :

\footnotetext{
${ }^{20}$ Indung Wijayanto.Kebijakan Pidana Denda di KUHP dalam Sistem Pemidanaan Indonesia. Jurnal. Pandecta.Volume 10. Nomor 2. December 2015.ISSN 1907-8919 (Cetak) ISSN 2337-5418 (Online) hlm. 249.

${ }^{21}$ Adami Chazawi, Pelajaran Hukum Pidana I, Raja Grafindo Persada, Jakarta, 2006, hlm. 41.

${ }^{22}$ Adriano. Pidana Pengganti Denda Sebagai Bentuk Substitusi Pidana Dalam Pertanggungjawaban Pidana Korporasi. Justitia Jurnal Hukum Fakultas Hukum Universitas Muhammadiyah Surabaya.Volume 1 No.1 April 2017ISSN Cetak: 2579-9983.E-ISSN: 2579-6380. hlm. 168.

${ }^{23}$ Ibid. hlm.169.
}

1. berdasarkan kasta orang yang bersalah, dan kepada siapa kesalahan tersebut diperbuat;

2. berdasarkan akibat yang diderita oleh orang atau binatang yang terkena;

3. berdasarkan perincian anggota yang terkena;

4. berdasarkan waktu berlakunya perbuatan;

5. berdasarkan niat orang yang berbuat salah;

6. berdasarkan jenis barang/binatang yang menjadi objek perbuatan.

Apabila denda tidak dibayar maka orang yang bersalah harus menjadi hamba atau budak dengan menjalankan segala apa yang diperintahkan tuannya. Bila hutang denda dapat dilunasi maka setiap saat ia dapat berhenti menjadi hamba dan yang berhak menetapkan berapa lama seorang yang bersalah itu menghamba untuk melunasi hutang dendanya adalah raja yang berkuasa. ${ }^{24}$

Pidana denda merupakan salah satu jenis pidana pokok dalam hukum pidana Indonesia yang merupakan bentuk pidana tertua dan lebih tua dari pidana penjara dan setua pidana mati. Pidana denda terdapat pada setiap masyarakat, termasuk masyarakat primitif walaupun bentuknya bersifat primitif karena sejak zaman Majapahit mengenal pidana denda tersebut. $^{25}$

Pidana denda adalah hukuman berupa kewajiban bagi seseorang yang telah melanggar larangan dalam rangka mengembalikan keseimbangan hukum atau menebus kesalahan dengan pembayaran sejumlah uang tertentu. Pidana denda tersebut diancamkan sebagai alternatif dengan pidana kurungan terhadap hampir semua pelanggaran yang ditentukan dalam Buku II dan Buku III KUHP dan Undangundang diluar KUHP. Penjatuhan pidana denda sebagai alternatif dari pidana perampasan kemerdekaan jangka pendek yang merupakan jenis pidana pokok yang paling jarang dijatuhkan oleh para hakim, khususnya dalam praktek peradilan di Indonesia. ${ }^{26}$

Hukum pidana adalah hukum yang mengatur tentang pelanggaran dan kejahatan terhadap kepentingan umum. Pelanggaran dan kejahatan tersebut diancam dengan hukuman yang merupakan penderitaan atau siksaan bagi yang bersangkutan. Kejahatan adalah

\footnotetext{
${ }^{24}$ Andi Hamzah, Sistem Pidana Dan Pemidanaan Di Indonesia, PT Pradnya Paramita, Jakarta, 1993. hlm. 14.

${ }^{25} \mathrm{Ibid}, \mathrm{hlm} .53$.

${ }^{26} \mathrm{Ibid}, \mathrm{hlm} .56$
} 
perbuatan pidana yang berat. Ancaman hukumannya dapat berupa hukuman denda, hukuman penjara, hukuman mati dan kadangkala masih ditambah dengan hukuman penyitaan barang-barang tertentu, pencabutan hak-hak tertentu serta pengumuman keputusan hakim. ${ }^{27}$

Tujuan hukum pidana ada dua macam, yaitu:

1. Untuk menakut-nakuti setiap orang agar tidak melakukan perbuatan pidana (fungsi preventif/pencegahan);

2. Untuk mendidik orang yang telah melakukan perbuatan pidana agar menjadi orang yang baik dan dapat diterima kembali dalam masyarakat (fungsi represif) kekerasan.

Jadi dapat disimpulkan bahwa tujuan hukum pidana adalah untuk melindungi masyarakat. Apabila seseorang takut untuk melakukan perbuatan tidak baik, karena takut dihukum, semua orang dalam masyarakat akan tenteram dan aman. ${ }^{28}$

\section{PENUTUP}

\section{A. Kesimpulan}

1. Bentuk-bentuk perbuatan pelaku usaha pangan yang dapat dikenakan sanksi hukum seperti menimbun atau menyimpan pangan pokok melebihi jumlah maksimal. Menimbun adalah menyimpan melebihi batas yang diperbolehkan dengan maksud untuk memperoleh keuntungan yang mengakibatkan harga pangan pokok menjadi mahal dan/atau melambung tinggi dan pelaku usaha pangan yang dengan sengaja tidak memiliki izin edar terhadap setiap pangan olahan yang dibuat di dalam negeri atau yang diimpor untuk diperdagangkan dalam kemasan eceran.

2. Pemberlakuan sanksi hukum terhadap pelaku usaha pangan akibat melakukan pelanggaran seperti menimbun atau menyimpan pangan pokok melebihi jumlah maksimal, maka pelaku usaha pangan dikenai sanksi administratif, berupa: denda; penghentian sementara dari kegiatan, produksi, dan/atau

\footnotetext{
${ }^{27}$ Yulies Tiena Masriani, Pengantar Hukum Indonesia, Cetakan Kelima, Sinar Grafika, Jakarta. 2009. hlm. 60.

${ }^{28}$ Ibid, hlm. 61.
}

peredaran; dan/atau pencabutan izin Apabila pelaku usaha pangan terbukti melakukan perbuatan dengan unsur kesengajaan maka dapat dikenakan pidana penjara paling lama 7 (tujuh) tahun atau denda paling banyak Rp100.000.000.000,00 (seratus miliar rupiah). Pelaku Usaha Pangan yang dengan sengaja tidak memiliki izin edar terhadap setiap pangan olahan yang dibuat di dalam negeri atau yang diimpor untuk diperdagangkan dalam kemasan eceran dipidana dengan pidana penjara paling lama 2 (dua) tahun atau denda paling banyak Rp4.000.000.000,00 (empat miliar rupiah).

\section{B. Saran}

1. Terjadinya bentuk-bentuk perbuatan pelaku usaha pangan yang dapat dikenakan sanksi hukum dapat dicegah apabila pemerintah menyelenggarakan program pemantauan, evaluasi, dan pengawasan secara berkala terhadap kegiatan atau proses produksi, penyimpanan, pengangkutan, dan/atau peredaran pangan oleh pelaku usaha panganDalam melaksanakan pengawasan, lembaga pemerintah sesuai dengan urusan dan/atau tugas serta kewenangan, masing-masing mengangkat pengawas. Dalam hal hasil pemeriksaan oleh pengawas menunjukkan adanya bukti awal bahwa telah terjadi tindak pidana di bidang pangan, penyidikan segera dilakukan oleh penyidik yang berwenang sesuai dengan ketentuan peraturan perundangundangan.

2. Pemberlakuan sanksi hukum terhadap pelaku usaha pangan akibat melakukan pelanggaran terhadap Undang-Undang Nomor 18 Tahun 2012 tentang Pangan, perlu diterapkan sesuai dengan peraturan perundang-undangan yang berlaku sesuai dengan perbuatan yang telah terbukti secara sah dilakukan oleh pelaku usaha pangan. Hal ini penting diberlakukan untuk memberikan efek jera terhadap pengurus dan/atau korporasi yang melakukan tindak pidana pangan dan bagi pihak-pihak lain lain 
sebagai suatu peringatan untuk tidak melakukan perbuatan yang sama.

\section{DAFTAR PUSTAKA}

Adriano. Pidana Pengganti Denda Sebagai Bentuk Substitusi Pidana Dalam Pertanggungjawaban Pidana Korporasi. Justitia Jurnal Hukum Fakultas Hukum Universitas Muhammadiyah Surabaya.Volume 1 No.1 April 2017ISSN Cetak: 25799983.E-ISSN: 2579-6380.

Chazawi Adami, Pelajaran Hukum Pidana I, Raja Grafindo Persada, Jakarta, 2006.

Hamzah Andi, Terminologi Hukum Pidana, (Editor) Tarmizi, Ed. 1. Cet. 1. Sinar Grafika, Jakarta, 2008.

Hamzah Andi, Sistem Pidana Dan Pemidanaan Di Indonesia, PT Pradnya Paramita, Jakarta, 1993.

Handayani Tini, Fungsionalisasi Hukum Pidana Terhadap Perbuatan Perdagangan Organ Tubuh Manusia (Khusus Ginjal Untuk Kepentingan Transplantasi CV. Mandar Maju, Cetakan ke-l. Bandung, 2012.

Hartanti Evi, Tindak Pidana Korupsi, Ed. 2. Cet. 1. Sinar Grafika, Jakarta, 2007.

HR. Ridwan. Hukum Administrasi Negara. UII Press. Yogyakarta. 2003.

Kristiyanti Tri Siwi Celina, Hukum Perlindungan Konsumen, Edisi I. Cetakan Pertama. Sinar Grafika. Jakarta, 2008.

Mahrus Ali, Dasar-Dasar Hukum Pidana, Cetakan Pertama, Sinar Grafika, Jakarta, 2011.

Masriani Tiena Yulies. Pengantar Hukum Indonesia, Cetakan Kelima, Sinar Grafika, Jakarta. 2009.

Miru Ahmadi dan Sutarman Yodo, Hukum Perlindungan Konsumen, PT RajaGrafindo Persada, Jakarta, 2008.

Moeljatno, Asas-Asas Hukum Pidana, Edisi Revisi, PT. Rineka Cipta, Jakarta, 2008.

Mudrieq Hs Sulfitri. Problematika Krisis Pangan Dunia Dan Dampaknya Bagi Indonesia.JURNAL ACADEMICA Fisip Untad. VOL.06 No. 02 Oktober 2014.

Muladi dan Dwidja Priyatno, Pertanggungjawaban Pidana Korporasi, Kencana Prenada Media Group, Jakarta, 2010.
Mulyadi Mahmud dan Feri Antoni Surbakti, Politik Hukum Pidana Terhadap Kejahatan Korporasi, Cetakan Pertama, PT. Sofmedia, Jakarta. 2010.

Nainggolan Kaman. Dewas Perum BULOG.Persoalan Pangan Global dan Dampaknya TerhadapKetahanan Pangan Nasional Artikel. PANGAN, Vol. 20 No. 1 Maret 2011.

Notoatmodjo Soekidjo, Etika \& Hukum Kesehatan, Rineka Cipta, PT. Rineka Cipta, Jakarta, 2010, hal. 81.

Nuh Muhammad, Etika Profesi Hukum, CV Pustaka Setia, Bandung, 2011.

Purwaningsih Yunastiti. Ketahanan Pangan: Situasi, Permasalahan, Kebijakan, Dan Pemberdayaan Masyarakat. Jurnal Ekonomi Pembangunan.Vol. 9, No. 1, Juni 2008.

Rahman Zaqiu. Problematika Penegakan Hukum Terhadap Pelaku Tindak Pidana Penimbunan Pangan. RechtsVinding Online. Jurnal RechtsVinding. Media Pembinaan Hukum Nasional.

Ridwan Juniarso H. dan Achmad Sodik Sudrajat, Hukum Adminsitrasi Negara dan Kebijakan Pelayanan Publik, Cetakan I. Nuansa. Bandung. 2010.

Silondae Akbar Arus dan Wirawan B. Ilyas, Pokok-Pokok Hukum Bisnis, Salemba Empat, Jakarta, 2011.

Soekanto Soerjono dan Sri Mamudji, Penelitian Hukum Normatif Suatu Tinjauan Singkat, PT Raja Grafindo Persada, Jakarta. 1995.

Spelt N.M. dan J.B.J.M. ten Berge, Pengantar Hukum Perizinan, (Penyunting) Philipus. M. Hadjon, Yuridika. Surabaya. 1993.

Sudarsono, Kamus Hukum, Cet. 6. Rineka Cipta, Jakarta, 2009.

Sunarso Siswantoro, Hukum Pidana Lingkungan Hidup Dan Strategi Penyelesaian Sengketa, Cetakan Pertama, Rineka Cipta, Jakarta, 2005.

Suratman, dan H. Philips Dillah, Metode Penelitian Hukum. Alfabetah, Bandung. 2015.

Sutedi Adrian. Hukum Perizinan Dalam Sektor Pelayanan Publik, Sinar Grafika. Jakarta. 2011. 
Sutedi Adrian. Hukum Perizinan dalam Sektor Pelayanan Publik. Sinar Grafika. Jakarta. 2009.

Syaifullah Yunan.? Ketahanan Pangan Dan Pola Distribusi Beras Di Propinsi Jawa Timur. JEJAK.Journal of Economics and Policy. ISSN 1979-715X.

Syahrin Alvi, Beberapa Isu Hukum Lingkungan Kepidananaan, Cetakan Revisi, PT. Sofmedia, Jakarta, Mei 2009.

Wijayanto Indung. Kebijakan Pidana Denda di KUHP dalam Sistem Pemidanaan Indonesia. Jurnal. Pandecta.Volume 10. Nomor 2. December 2015.ISSN 1907-8919 (Cetak) ISSN 2337-5418 (Online).

Yamin Muhammad, Tindak Pidana Khusus, Cet. 1. Pustaka Setia, Bandung, 2012.

\section{INTERNET}

https://beritagar.id/kanal/berita.Tersangka beras Maknyuss dijerat pasal kecurangan pangan. Diakses 6/11/2019 3:03 Wita. 2:46 Wita.

https://republika.co.id/kanal/ekonomi/ekonom i'Kemendag Sita 670 Ton Bawang Bombai Impor llegal.Diakses 6/11/2019 3:03 Wita.

https://www.cnnindonesia.com/nasional/2014 1208150115-12-16675/pengoplos-minumankeras-diancam-undang-undangpangan\#Diakses 6/11/2019 3:03 Wita. 2:48 Wita.

https://republika.co.id/kanal/ekonomi/ekonom i. Petani Tolak Politisasi Sektor Pangan.Diakses 6/11/2019 3:03 Wita. 2:46 Wita. 